\title{
Anhysteretic remanent magnetic anisotropy and calcite strains in Devonian carbonates from the Appalachian Plateau, New York
}

\author{
MIKE JACKSON ${ }^{1 *}$, JOHN P. CRADDOCK ${ }^{1 * *}$, MARTHA BALLARD ${ }^{1 * * *}$, \\ ROB VAN DER VOO ${ }^{1}$ and CHAD MCCABE ${ }^{2}$ \\ 1 Department of Geological Sciences, the University of Michigan, Ann Arbor, MI 48109-1063 (U.S.A.) \\ 2 Department of Geology, Louisiana State University, Baton Rouge, LA 70803 (U.S.A.)
}

(Received March 16, 1988; revised version accepted July 15, 1988)

\begin{abstract}
Jackson, M., Craddock, J.P., Ballard, M., Van der Voo, R. and McCabe, C., 1989. Anhysteretic remanent magnetic anisotropy and calcite strains in Devonian carbonates from the Appalachian Plateau, New York. Tectonophysics, 161: $43-53$.

Anisotropy of anhysteretic susceptibility (AAS) is a recently developed high-resolution method of measuring the magnetic fabric of rocks. In order to test the applicability and limitations of AAS for estimation of strain orientations in weakly-deformed and weakly magnetic rocks, we have used the method to examine the magnetic fabric of samples from a series of sites in limestones of the Helderberg and Onondaga formations along a $500-\mathrm{km}$ E-W transect across New York State. Two distinct shortening directions have been previously identified and interpreted in terms of two separate phases of Alleghenian deformation. Over most of the transect, minimum anhysteretic susceptibility axes within the plane of bedding closely parallel the compression direction of the earlier ("Lackawanna") phase. A few sites show minimum anhysteretic susceptibility parallel to the later ("Main") phase. The threshold for resolution of the tectonic signal by AAS is at anhysteretic susceptibilities of about $2 \times 10^{-5}$ (SI) and strain magnitudes of 0.5 to $1 \%$ as recorded by twinning in calcite. The central part of the transect exhibits minimum horizontal anhysteretic susceptibility perpendicular to the inferred tectonic compression, rather than parallel to it. We attribute this to either: (a) anisotropic transmission of stresses from the larger calcite matrix grains to the smaller magnetite grains during twinning; or (b) preferential recording of a late-stage non-coaxial stress direction in this area by late diagenetic magnetite.
\end{abstract}

\section{Introduction}

The information obtained from measurements of magnetic anisotropy depends in part upon the type of magnetization involved. The primary distinction is between induced magnetization (measured in the presence of an applied magnetic field)

Present addresses:

* Department of Geology and Geophysics, University of Minnesota, Minneapolis, MN 55455 (U.S.A.).

** 100 Kinross \#56, Walnut Creek, CA 94598 (U.S.A.). *** 7208 Leslynne NE, Albuquerque, NM 87109 (U.S.A.). and remanent magnetization (measured in the absence of a field). Remanent magnetization resides solely in ferromagnetic trace minerals, chiefly magnetite and hematite, and anisotropy of remanent magnetization reflects the preferred orientations of these grains. In contrast, virtually all rock-forming minerals acquire an induced magnetization in the presence of a weak magnetic field (i.e, they have a non-zero magnetic susceptibility). Anisotropy of magnetic susceptibility (AMS), measured in the presence of an applied ficld, thus represents an average preferred orientation of all the mineral grains in a rock, weighted according to their relative susceptibilities, concentrations, grain 
anisotropies, and degree of alignment (Hrouda, 1982).

Studies to date comparing the anisotropies of remanent and induced magnetization (Fuller, 1963; Daly and Zinsser, 1973; McCabe et al., 1985; Stephenson et al., 1986) have shown that remanent anisotropies tend to be significantly larger and better-defined than susceptibility anisotropy. This was attributed by Fuller (1963) and by McCabe et al. (1985) to elimination of the relatively isotropic contribution of the diamagnetic or paramagnetic matrix material. Even when the matrix material has a strong preferred crystallographic orientation, the relatively small grain anisotropies cause the contribution of the dia- or paramagnetic fraction to the overall susceptibility to be only weakly anisotropic. Thus, although some attention has recently been focussed on paramagnetic anisotropy (Owens and Rutter, 1978; Hounslow, 1985; Borradaile et al., 1986, 1987; Hrouda, 1987), the dominant effect of paramagnetic matrix susceptibility in most rocks is to "dilute" the anisotropy of the ferromagnetic fraction (Fuller, 1963). Further, Stephenson et al. (1986) show that particle anisotropies for magnetite are much larger for remanent magnetizations than for susceptibility. Elongate single-domain magnetites will have their remanence parallel to their long axes regardless of the applied magnetic field orientation, giving them a virtually infinite grain anisotropy for remanence (Stephenson et al., 1986).

This has two immediate and important consequences. First is that the stronger remanent anisotropies can be expected to yield superior resolution of the directions and magnitudes of the principal magnetic axes. The second is that whereas the magnitude of the anisotropy is a strong function of the weight percentage of ferromagnetic material in the case of induced magnetization (Fuller, 1963; Henry, 1983; Rochette and Vialon, 1984; Lamarche and Rochette, 1987; Borradaile, 1987 ), it is theoretically independent of concentration for remanent magnetization (Stephenson et al., 1986). Remanence anisotropy may therefore be of more use in structural studies than the conventionally-utilized AMS, especially in studies of weakly-deformed and/or weakly magnetic rocks. While AMS has proven to be a valuable tool in many deformation studies (e.g., Rathore, 1979; Kligfield et al., 1982; MacDonald and Ellwood, 1987), it has also proven to be difficult to quantify accurately, especially in rocks with low bulk susceptibility or weak anisotropy (Hrouda et al., 1983; Ellwood, 1984).

McCabe et al. (1985) measured the anisotropies of both anhysteretic remanence and induced magnetization in a set of Ordovician Trenton Limestone samples, and found that the former yielded a better-resolved magnetic fabric, which they attributed to Pennsylvanian-Permian Alleghenian deformation. In this paper we apply the methods of McCabe et al. to a traverse along the northern margin of the Appalachian Basin, following the outcrop belt of the Devonian Helderberg and Onondaga limestones, as a test of the applicability and limitations of those methods. These units have been thoroughly studied from both structural (e.g., Engelder, 1979; Geiser and Engelder, 1983; Bosworth, 1984) and rock-magnetic (e.g., Kent, 1979, 1985; Scotese et al., 1982; Jackson et al., 1988) standpoints, which facilitates evaluation of the results.

\section{Geologic setting}

The Devonian carbonates which are the subject of this study are exposed along a belt extending from the north shore of Lake Erie eastward to the Hudson Valley near Albany, N.Y., then southward into Pennsylvania (Fig. 1). The Helderberg and overlying Onondaga carbonates are generally fine-grained, gray-colored limestones, essentially flat-lying over the entire study area, and showing no obvious signs of deformation. However, a number of previous studies have documented northerly to northwesterly layer-parallel shortening (Fig. 2), manifested by deformed fossils (Engelder and Engelder, 1977; Engelder and Geiser, 1979), mechanical twinning in calcite (Engelder, 1979; Craddock and Van der Pluijm, 1987), pencil and solution cleavage development (Engelder and Geiser, 1979), and cross-fold jointing (Engelder and Geiser, 1980; Engelder and Oertel, 1985).

A series of broad gentle anticlines striking roughly E-W were mapped by Wedel (1932) in 
south-central New York. These folds are apparently restricted to the area underlain by the Silurian Salina Salt, which provided a regional décollement (Frey, 1973; Wiltschko and Chapple, 1977). Farther east, where this salt horizon is absent, the stratigraphically-higher Union Springs Shale acted locally as a detachment for westnorthwesterly overthrusting (Bosworth, 1984).

Geiser and Engelder (1983) have interpreted Alleghenian deformation as a two-stage event, with tectonic compression initially directed in a northwesterly direction (Lackawanna phase), subsequently becoming more northerly (Main phase). In the Hudson Valley, it is uncertain if the deformation is dominantly Acadian or Alleghenian (Marshak, 1986, and references therein). Previous studies of magnetic anisotropy in the Hudson Valley have shown a consistent pattern, with minimum susceptibility axes lying in a vertical plane striking approximately WNW, parallel to the direction of maximum compression (Graham, 1967; Kent, 1979; Marshak, 1986). However this pattern appears to be restricted to the Hudson Valley. At Clarksville, N.Y., only a few miles west of the Hudson Valley, tectonic effects in the AMS data are only faintly discernible (Graham, 1967; Kent, 1979). Our study was designed to investigate how far west along the profile the tectonically-induced fabric of magnetite grains could be recognized in the remanent anisotropy.

\section{Methods}

\section{Sampling}

Oriented cores were drilled at 15 sites in the Onondaga Formation and at eight sites in the Helderberg Formation (Fig. 1). A minimum of seven cores were obtained at each site. Orientation was performed by magnetic compass. Where joints were present their orientations were also measured. The sample cores were cut in the laboratory into standard 2-cm length cylindrical specimens. Storage and measurement of the specimens took place in a magnetically-shielded room.

\section{Anisotropy}

Magnetic fabric was determined by measuring the directional anisotropy of anhysteretic suscept- ibility (AAS), as described by McCabe et al. (1985). Each specimen was initially demagnetized in an alternating field (AF) of $100 \mathrm{mT}$. An anhysteretic remanent magnetization (ARM) was then imparted to the specimen at a specified orientation, in an $\mathrm{AF}$ of $30 \mathrm{mT}$ with a superimposed steady field of $0.1 \mathrm{mT}$, using a Schonstedt AC demagnetizer. The intensity of the ARM acquired, normalized hy the applied steady field, is termed the anhysteretic susceptibility, $k_{\text {a }}$ (King et al., 1982), which is a measure of the degree of alignment of the magnetic particles in that direction. The procedure was repeated for nine different orientations for each specimen, and the anhysteretic susceptibility tensor (a symmetric second rank tensor defined by six independent quantities) was therefore overdetermined, and could be computed by least-squares to yield both the orientation and the goodness-of-fit of the ARM ellipsoid (Girdler, 1961). The differences between the least-squares solution and the measured anhysteretic susceptibility values provide an indication of how well the data are described by the ellipsoid. The rootmean-square of these residuals was rarely as large as $5 \%$ of the measured values, and most often was less than $2 \%$. When the RMS residuals exceeded $10 \%$ of the measured values, the specimen was discarded from the analysis. In addition to the three-dimensional ARM ellipsoid, the measured values were also used to compute a two-dimen-

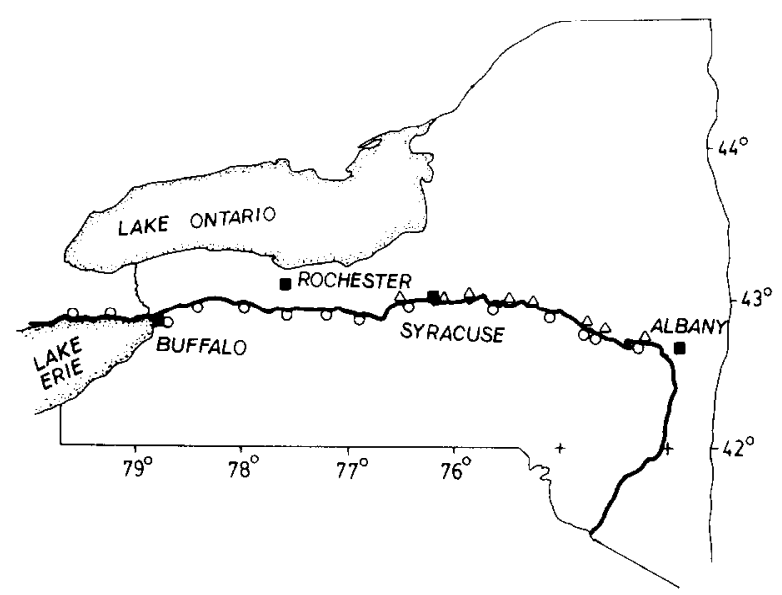

Fig. 1. Index map of New York State showing location of sampling sites. The heavy line shows the outcrop belt of the Devonian Helderberg and Onondaga carbonate strata. Circles represent Onondaga sites, triangles represent Helderberg sites. 


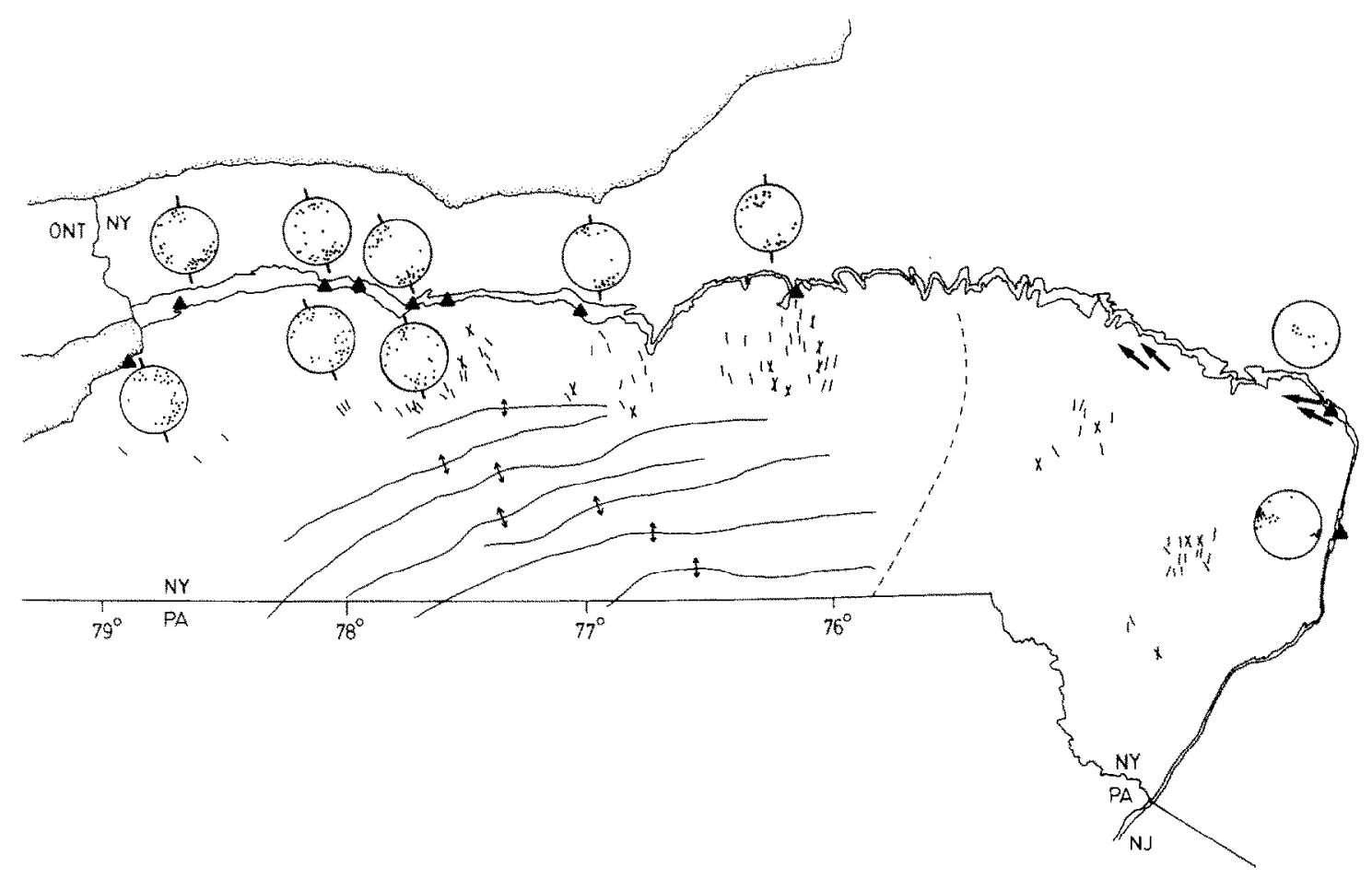

Fig. 2. Summary of structural features identified by previous workers. Patterned area shows the outcrop of Lower and Middle Devonian carbonates. Long thin lines are anticlinal hinges mapped by Wedel (1932); dashed line is the approximate eastern limit of the Silurian Salina salt in the subsurface (Frey, 1973); short lines are set I joint orientations from Engelder and Geiser (1980); bold arrows show direction of overthrusting in the Union Springs shale (Bosworth, 1984); the two stereoplots in the east show orientations of minimum magnetic susceptibility axes; triangles are corresponding sample localities (Graham, 1967; Marshak, 1986); remaining stereoplots show calcite twin compression axes (Engelder, 1979); heavy lines on stereoplot margins show horizontal compression direction, and triangles show sample localities.

sional ARM ellipse within the plane of bedding, for comparison with available layer-parallel strain estimates.

\section{Calcite twin analysis}

Quantitative strain estimates based on mechanical twinning in calcite (Groshong, 1972, 1974) were reported by Engelder (1979) for much of the western and central portion of our transect. We have obtained complementary data for the eastern and far western parts by measuring calcite twins in samples from seven sites. At least fifteen grains were measured for each sample. The strain ellipsoid and principal strain axes for each sample were determined by the method of Groshong (1972), and consistency of the data was evaluated by the number of grains with negative expected values (Teufel, 1980). Compression axes for individual grains were also contoured to infer a best estimate for the orientation of the maximum principal compressive paleostress at the time of twinning (Turner, 1953).

\section{Results}

\section{Calcite twin analysis}

Contoured stereoplots of compression axes determined by calcite twin analysis are shown in Fig. 3. All of the samples analyzed record layer-parallel shortening directions that coincide with the inferred regional Alleghenian thrust transport directions (cf. Fig 2). The maximum shortening and principal compression directions were identical 
within each sample, and shortening strain magnitudes ranged from $-0.25 \%$ to $-0.8 \%$. Our data were internally very consistent, with an average of $5 \%$ negative expected values as well as low nominal errors for all of the seven samples.

\section{Anisotropy of anhysteretic susceptibility}

Figure 3 also shows the distribution of axes of minimum anhysteretic susceptibility within the plane of bedding. Over the eastern part of the transect, the horizontal minimum $k_{\mathrm{a}}$ axes and the calcite-twin compression axes are mostly oriented west-northwesterly, in good agreement with the direction overthrusting in the Union Springs shale (Bosworth, 1984) and with the pattern (Fig. 2) of magnetic anisotropy measured previously within the Hudson valley (Graham, 1967; Kent, 1979; Marshak, 1986). Westward, toward Utica, the minimum $k_{\mathrm{a}}$ axes become more northerly, in reasonable accord with the calcite twin compression and shortening directions and set Ia joint orientations.

From Utica westward, the minimum $k_{\mathrm{a}}$ axes become progressively more westerly, and more discordant with the generally northward shorten- ing indicated by the cleavage, jointing and calcite twinning in these rocks (Fig. 3). However the directional consistency of the minimum $k_{\mathrm{a}}$ axes remains quite strong, until it decreases abruptly at a point between Syracuse and Rochester. There is some indication of a preferred orientation parallel to the regional north-northwesterly compression at a few of the western sites, notably at the two westernmost sites. However the signature of regional Alleghenian shortening is in general poorly resolved or absent in the AAS of the sites in the western half of the transect.

Part of the reason for the high dispersion of the minimum $k_{\mathrm{a}}$ axes over the western part of the profile can be seen in Fig. 4. The magnitude of the layer-parallel calcite twin shortening strain is very small across the entire transect. It is only in the central area, near Syracuse, that strains greater than $1 \%$ are recorded, and over the western half the magnitude of the twin shortening is generally less than $0.5 \%$. The decrease in twinning strains westward from Syracuse was attributed by Engelder (1979) to increasing distance from the Alleghenian front. The decrease in strain magnitude from Syracuse eastward is probably due in part to differential partitioning of the bulk strain among several deformational mechanisms, and to lower

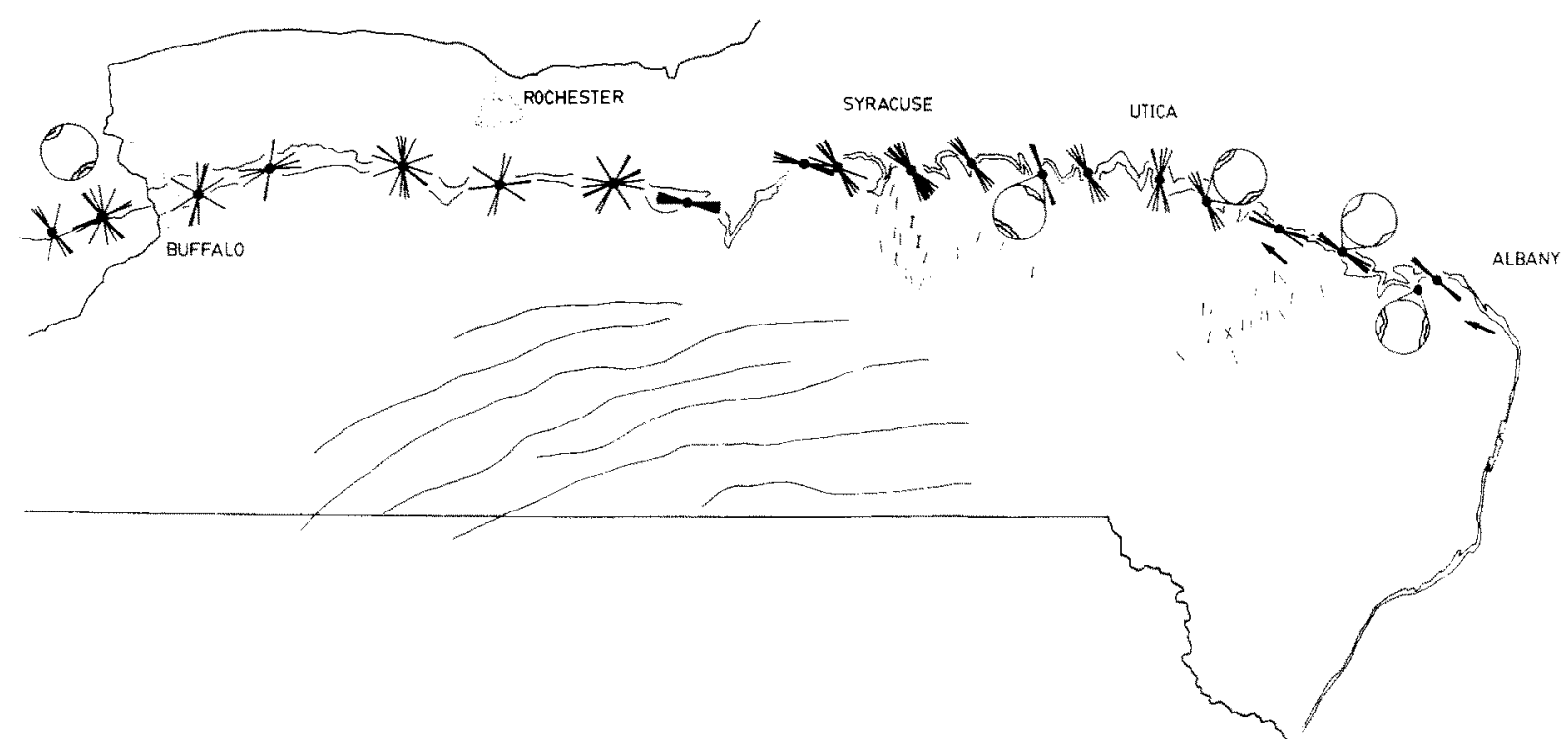

Fig. 3. Orientation of the minimum horizontal susceptibility axes (lines) at each sampling site (solid circles). Contours on the stereoplots show distribution of calcite twin compression axcs. Fold axcs, thrust directions, and joint orientations as in Fig. 2. 
Calcite Strain Magnitude

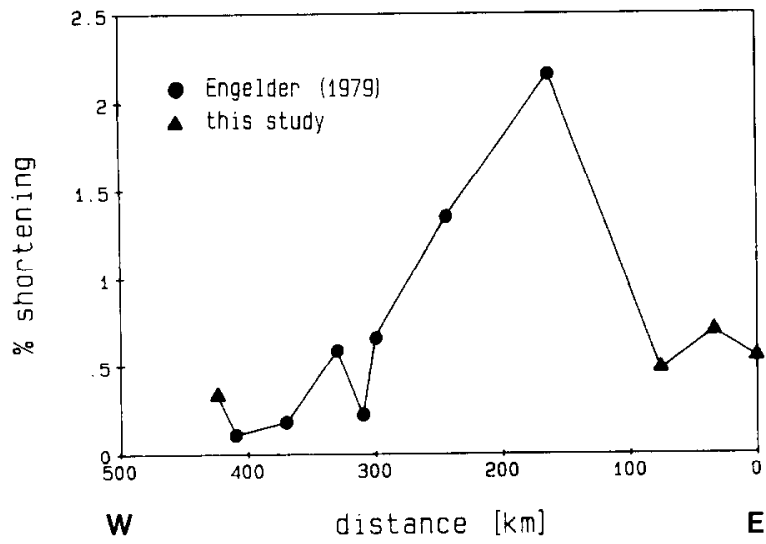

Fig. 4. Magnitude of layer-parallel shortening strain due to mechanical twinning in calcite along the transect. Distances in kilometers west of site 1 .

regional differential stresses where the underlying salt decollement is absent. We will return to this point in the interpretation section below.

The inconsistency in minimum $k_{\mathrm{a}}$ axis orientations over the western part of the transect is also related to generally lower concentrations of magnetite in the rocks. Figure 5 shows the site mean values of anhysteretic susceptibility $k_{\text {mean }}$. A strong linear correlation between $k_{\text {mean }}$ and low-ficld susceptibility $k$ (Jackson et al., 1988) indicates fairly uniform magnetic grain sizes, with a variable weight percentage of magnetite present (King et al., 1982). Variations in $k_{\text {mean }}$ therefore primarily reflect variations in the concentration of

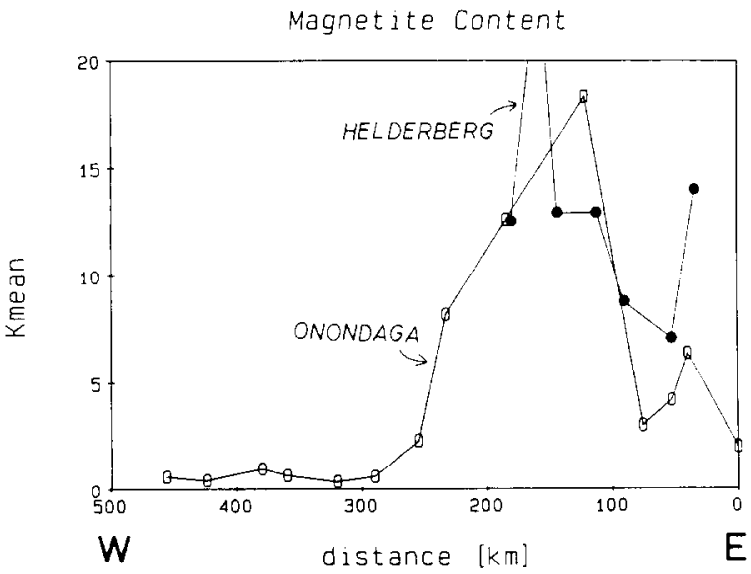

Fig. 5. Mean values of anhysteretic susceptibility along the sampling profile. Open symbols represent Onondaga samples, solid for Helderberg; units are $10^{-5}$ S.I.

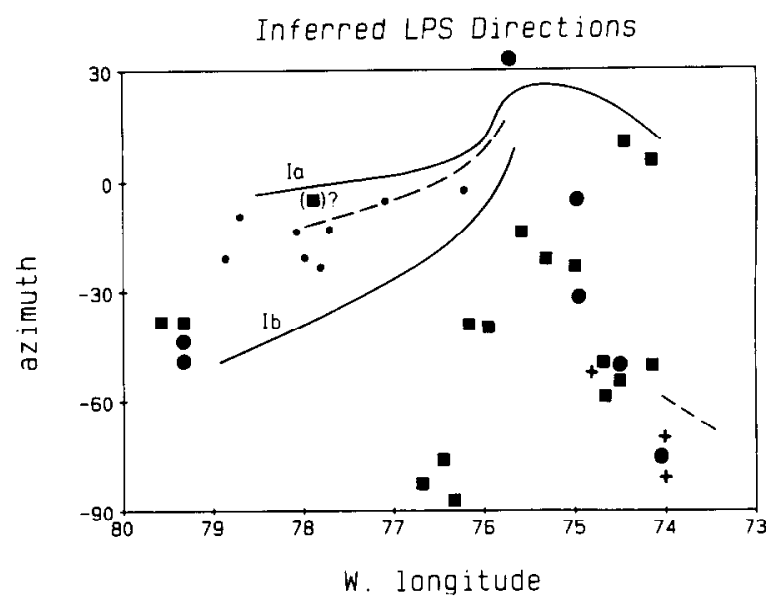

Fig. 6. Azimuthal variation of various compression indicators along the transect. Dashed lines: normal to cleavage trend lines (Geiser and Engelder, 1983); solid lines: set la and set Ib joints (Engelder and Geiser, 1980); + : overthrust transport direction in the Union Springs shale (Bosworth, 1984); dots: calcite twin maximum horizontal compression direction (Engelder, 1979); filled circles: calcite twin maximum horizontal compression and shortening directions (this study); squares: site modal horizontal anhysteretic susceptibility minimum (this study).

magnetite (Jackson et al., 1988). The low magnetite concentrations, coupled with the low strains, probably account for the inconsistent directional results for the western sites. The resolution threshold for AAS therefore appears to be at about $0.5 \%$ calcite twin strain (assuming that the AAS and calcite twins developed synchronously) and $2 \times 10^{-5}$ (S.I.) anhysteretic susceptibility.

Figure 6 summarizes all directional data derived from the present and previous structural studies. In the eastern part of the transect (east of $75.5^{\circ} \mathrm{W}$. longitude) there are two clearly defined azimuthal trends. A generally northerly compression $\left(0^{\circ}\right.$ to $\left.30^{\circ}\right)$ is evidenced by the set Ia joints of Engelder and Geiser (1980) and by susceptibility minima at several sites. Calcite twin compression and shortening directions at three sites are within $30^{\circ}$ of this trend.

A northwesterly compression $\left(280-340^{\circ}\right)$ is very clearly delineated by the normals to cleavage (Geiser and Engelder, 1983), overthrust slip directions in the Union Springs shale (Bosworth, 1984) and our calcite twin shortening and compression directions and minimum susceptibility axis orientations (Fig. 6). These data correspond to the 
Lackawanna (early Alleghenian) deformational phase of Geiser and Engelder (1983). The compression azimuth varies systematically along the transect from about $290^{\circ}$ at $74^{\circ} \mathrm{W}$ to about $340^{\circ}$ at $75.5^{\circ} \mathrm{W}$.

West of $75.5^{\circ} \mathrm{W}$, the transect is underlain by the Salina salt (Frey, 1973), and features related to the northward-directed Main phase Alleghenian compression (Geiser and Engelder, 1983) are more evident. Set Ia joints and normals to cleavage are generally oriented between $350^{\circ}$ and $360^{\circ}$, except near the eastern salt boundary, where they show a clockwise rotation of some $10^{\circ}$ to $20^{\circ}$. Set $\mathrm{Ib}$ joints are oriented about $30^{\circ}$ more westerly and are associated by Geiser and Engelder (1983) with the Lackawanna phase. The calcite twin compression axes of Engelder (1979) all lie between the azimuths of the set Ia and set Ib joints, as do our calcite twin compression and shortening axes at the west end of the transect, and the minimum horizontal susceptibility axes west of $77^{\circ} \mathrm{W}$. Between about $76^{\circ}$ and $77^{\circ}$ longitude, the minimum susceptibility axis orientations depart strongly from the characteristic tectonic compression azimuth of either Alleghenian deformational phase.

\section{Discussion}

\section{Source of anisotropy}

Paleomagnetic and rock magnetic studies of the Onondaga (Kent, 1979, 1985) and Helderberg (Scotese et al., 1982) strata have demonstrated that: (1) the bulk magnetic properties of these units are dominated by multidomain magnetite; and (2) this magnetite carries a well-defined natural remanence much younger than the rocks, i.e., of Late Paleozoic age. McCabe et al. (1983) proposed a Late Paleozoic diagenetic origin for the magnetite, based on the chemistry and morphology of grains observed in magnetic extracts. $\mathrm{X}$-ray diffraction patterns show a complete lack of $\mathrm{Ti}$ or other Fe-substituting cations which are usually found in extraterrestrial or volcanically-derived magnetites (McCabe et al., 1983). In-situ formation is suggested by the commonly hollow spheroidal or botryoidal polycrystalline aggregate morphology of magnetites observed by SEM.

The pattern of variation in magnetite concentration (Fig. 5) is distinctly similar to the pattern of variation in illite/smectite ratio and apatite fission-track apparent ages reported by Johnsson

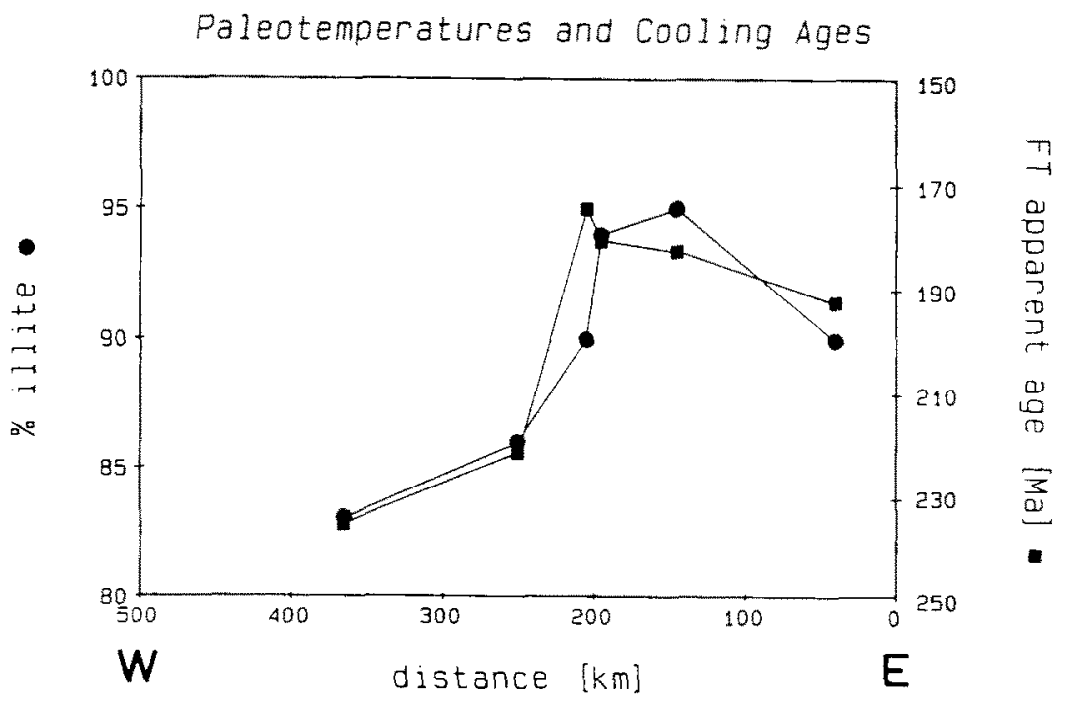

Fig. 7. Indicators of thermal history along the profile, from Johnsson (1986). Full circles represent the fraction of illite in illite/smectite; squares show apatite fission-track apparent ages. The peak near Syracuse is interpreted in terms of deeper burial and later uplift, and correlates with the peaks in $k_{\text {mean }}$ (Fig. 5) and calcite twin strain magnitudes (Fig. 4). 
(1986) for the same transect (Fig. 7). Diagenetic transformation of smectite to illite is temperature dependent, and Johnsson (1986) interprets the data of Fig. 7 in terms of differences in the diagenetic temperature history along the transect. The correlation between $k_{\text {mean }}$, reflecting magnetite concentration, and illite content, reflecting diagenetic paleotemperatures, is statistically significant and argues for a synchronous diagenetic development of magnetite and illite with a common dependence upon temperature. We present this argument in detail elsewhere (Jackson et al., 1988), but we note here that if it is correct, then it supports a Late Paleozoic age for almost all of the magnetite in these strata. We therefore conclude that the magnetic fabric we observe is exclusively Alleghenian. Any earlier Acadian deformation the strata may have undergone does not contribute to the observed magnetic anisotropy.

The anhysteretic magnetic anisotropy we have measured presumably arose either by realignment or by internal deformation of these magnetite grains. Where pressure solution is an important deformation mechanism, magnetite grains can be concentrated along solution fronts and realigned by simple grain rotation (Borradaile and Tarling, 1981). Where strain is accomplished dominantly hy mechanical twinning of calcite, some combination of internal deformation by gliding (Muller and Siemes, 1972) and simple rotation of magnetite grains may be operative. It is difficult to assess the actual mechanism by which the anisotropy arises, because it has not yet proven possible to observe the magnetite grains in-situ, but only in extracts, due to the very low concentrations present.

\section{Interpretation of results}

The variation in the magnitude of calcite twin shortening strains, though it follows the same pattern as magnetite and illite content, is not likely to be related to diagenesis. The westward decrease from the peak value near Syracuse can be best explained in terms of decreasing stresses with increasing distance from the orogenic front (Engelder, 1979). The eastward decrease may be explained in terms of weaker deformation in the

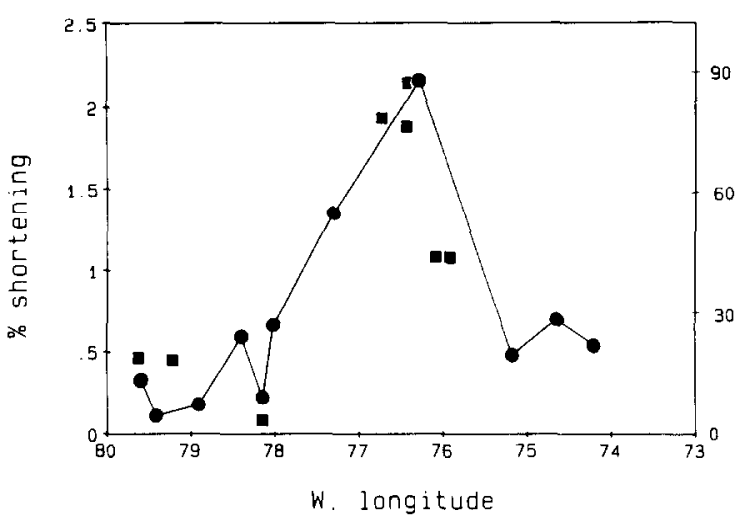

Fig. 8. Angular deviation (squares) of minimum susceptibility axes from compression directions inferred from joint orientations, calcite twinning, and normals to cleavage, compared to calcite twin \%strain (circles).

region where the underlying salt décollement is absent, or in terms of decreased twinning due to the somewhat finer grain size of the calcite there (Hugman and Friedman, 1979). Perhaps a better explanation involves the partitioning of strain between mechanical twinning and pressure solution (e.g. Groshong et al., 1984). Maximum burial temperatures (and depths), as indicated by conodont color alteration (Epstein et al., 1977) increased monotonically eastward along the transect. The increased temperatures and pressures would enhance calcite solubility and diffusivity, and deformation by pressure solution would be favored (Rutter, 1976) in comparison with calcite twinning, which is temperature-independent (Carter, 1976).

Where they are consistent, the orientations of the minimum susceptibility axes exhibit a clear relationship with tectonic compression directions, except, oddly, in the area between about $76^{\circ}$ and $77^{\circ} \mathrm{W}$, with the highest magnetite content and the largest twin strains. In fact the difference in azimuth between the minimum susceptibility axes and the compression direction inferred from other means is directly correlated with the magnitude of the twinning strains (Fig. 8).

There are several possible explanations for this surprising relationship. First, there may be some mechanism by which the relatively small magnetite particles experience a different stress orientation than the larger calcite matrix grains, as a 
consequence of deformation by twinning. If small magnetites occur as inclusions within the calcite grains, the shearing associated with twinning may tend to align them into the compression direction. This hypothetical alignment mechanism is difficult to evaluate because we are unable to observe the magnetites in-situ.

Alternatively, the different orientation of the susceptibility ellipsoids in this part of the transect may reflect a later-stage stress state. Graham (1967) saw evidence of late-stage compression parallel to fold axes in the AMS of Appalachian sediments, apparently corresponding to the onset of folding. Since the area between $76^{\circ}$ and $77^{\circ} \mathrm{W}$ was the latest to be uplifted (Johnsson, 1986), authigenic magnetite growth probably continued later than in the rest of the transect. Magnetite growing during this late phase would record only the last part of the deformation, with shortening perpendicular to the total finite compression.

\section{Summary and conclusions}

The principal axes of anhysteretic susceptibility in the Helderberg and Onondaga limestones on the Appalachian Plateau are in general closely related to the principal horizontal strains. Strain orientations are well resolved when the anhysteretic susceptibility is greater than about $2 \times 10^{-5}$ (S.I.) and when the calcite strain magnitudes are about $1 \%$ or greater.

In the eastern part of the transect and at a few sites in the western half, minimum horizontal anhysteretic susceptibility axes are parallel to the principal horizontal compression axis. This probably arises either by rotation of magnetite particle long axes away from the direction of compression, or by internal deformation of the larger magnetite grains, possibly by gliding (Muller and Siemes, 1972), or perhaps by crushing of the hollow polycrystalline aggregates.

Minimum susceptibility axes in the central portion of the transect are nearly perpendicular to the compression directions recorded by solution cleavage, calcite twinning, and joint orientations. This can be explained either in terms of anisotropic transmission of tectonic stress by the larger calcite grains to the smaller magnetites, or in terms of a late-stage compression along the direction of the fold axes, preferentially recorded in the fabric of younger magnetite in the central zone.

\section{Acknowledgments}

For assistance in the field, we are grateful to Sanford Ballard; for discussion of various related topics, we thank Andy Schedl, Ben van der Pluijm, and Don Peacor. The review by Graham Borradaile helped to clarify several points. Partial funding was provided by Conoco, Texaco, and NSF grants EAR 84-07007 and EAR 84-07083.

\section{References}

Borradaile, G., 1987. Anisotropy of magnetic susceptibility: rock composition versus strain. Tectonophysics, 138: 327329 .

Borradaile, G. and Tarling, D., 1981. The influence of deformation mechanisms on the magnetic fabrics in weakly deformed rocks. Tectonophysics, 77: 151-168.

Borradaile, G., Mothersill, J., Tarling, D. and Alford, C., 1986. Sources of magnetic susceptibility in a slate. Earth Planet. Sci. Lett., 76: 336-340.

Borradaile, G., Keeler, W., Alford, C. and Sarvas, P., 1987. Anisotropy of magnetic susceptibility of some metamorphic minerals. Phys. Earth Planet. Inter., 48: 161-166.

Bosworth, W., 1984. Foreland deformation in the Appalachian Plateau, central New York: the role of small-scale detachment structures in regional overthrusting. J. Struct. Geol., 6: $73-81$.

Carter, N.L., 1976. Steady state flow of rocks. Rev. Geophys. Space Phys., 14: 301-360.

Craddock, J.P. and Van der Pluijm, B., 1987. Migration of Late Paleozoic brines through cratonic carbonates by calcite twin 'pumping': a hypothesis. Geol. Soc. Am., Abstr. Prog., 19: 194.

Daly, L. and Zinsser, H., 1973. Étude comparative des anisotropies de susceptibilité et d'aimantation remanente isotherme: conséquences pour l'analyse structurale. Ann. Geophys., 29: 189-200.

Ellwood, B.B., 1984. Anisotropy of magnetic susceptibility: cmpirical evaluation of instrumental precision. Geophys. Res. Lett., 11: 645-648.

Engelder, T., 1979. The nature of deformation within the outer limits of the Central Appalachian foreland fold and thrust belt in New York State. Tectonophysics, 55: 289-310.

Engelder, T. and Engelder, P., 1977. Fossil distortion and décollement tectonics of the Appalachian Plateau. Geology, 5: $457-460$.

Engelder, T. and Geiser, P., 1979. The relationship between pencil cleavage and lateral shortening within the Devonian section of the Appalachian Plateau, New York. Geology, 7 : $460-464$ 
Engelder, T. and Geiser, P., 1980. On the use of regional joint sets as trajectories of paleostress fields during the development of the Appalachian Plateau, New York. J. Geophys. Res., 85: 6319-6341.

Engelder, T. and Oertel, G., 1985. Correlation between abnormal pore pressure and tectonic jointing in the Devonian Catskill Delta. Geology, 13: 863-866.

Epstein, A.G., Epstein, J.B. and Harris, L.D., 1977. Conodont color alteration-an index to organic metamorphism. U.S. Geol. Surv, Prof. Pap., 995, 27 pp.

Frey, M.G., 1973. Influence of Salina Salt on structure in New York-Pennsylvania part of Appalachian Plateau. Am. Assoc. Pet. Geol. Bull., 57: 1027-1037.

Fuller, M., 1963. Magnetic anisotropy and paleomagnetism. J. Geophys. Res., 68: 293-309.

Geiser, P. and Engelder, T., 1983. The distribution of layerparallel shortening fabrics in the Appalachian foreland of New York and Pennsylvania: evidence for two non-coaxial phases of the Alleghenian orogeny. Geol. Soc. Am., Mem., 158: $161-175$.

Girdler, R.W., 1961. The measurement and computation of anisotropy of magnetic susceptibility in rocks. Geophys. J. R. Astron. Soc., 5: 34-44.

Graham, J.W., 1967, Significance of magnetic anisotropy in appalachian sedimentary rocks. Am. Geophys. Union, Geophys. Monogr., 10: 627-648.

Groshong, R.H., Jr, 1972. Strain calculated from twinning in calcite. Geol. Soc. Am. Bull., 83: 2025-2038.

Groshong, R.H., Jr., 1974. Experimental test of least squares strain calculations using twinned calcite. Geol. Soc. Am. Bull., 85: 1855-1864.

Groshong, R.H. Jr., Pfiffner, O.A. and Pringle, L.R., 1984. Strain partitioning in the Helvetic thrust belt of eastern Switzerland from the leading edge to the internal zone. $\mathbf{J}$. Struct. Geol., 6: 5-18.

Henry, B., 1983. Interprétation quantitative de l'anisotropies de susceptibilité magnétique, Tectonophysics, 91: 165-177.

Hounslow, M.W., 1985. Magnetic fabric arising from paramagnetic phyllosilicate minerals in mudrocks. J. Geol. Soc. London, 142: 995-1006.

Hrouda, F., 1982. Magnetic anisotropy of rocks and its application in geology and geophysics. Geophys. Surv., 5: 37-82.

Hrouda, F., 1987. Mathematical model relationship between the paramagnetic anisotropy and strain in slates. Tectonophysics, 142: 323-327.

Hrouda, F., Stephenson, A. and Woltar, L., 1983. On the standardization of the anisotropy of magnetic susceptibility. Phys. Earth Planet Inter., 32: 203-208.

Hugman, R.H.H., III, and Friedman, M., 1979. Effects of texture and composition on mechanical behavior of experimentally deformed carbonate rocks. Bull. Am. Assoc. Pet. Geol, 63: 1478-1489.

Jackson. M.J., McCabe, C., Ballard. M.M. and Van der Voo, R., 1988. Magnetite authigenesis and diagenetic paleotemperatures across the northern Appalachian Basin. Geology, 16: 592-595.

Johnsson, M.J., 1986. Distribution of maximum burial temper- atures across the northern Appalachian Basin and implications for Carboniferous sedimentation patterns. Geology, 14: $384-387$.

Kent, D.V., 1979. Paleomagnetism of the Devonian Onondaga limestone revisited. J. Geophys. Res., 84: 3576-3588

Kent, D.V., 1985. Thermoviscous remanence in some Appalachian limestones. Geophys. Res. Lett., 12: 805-808.

King, J., Banerjee, S.K., Marvin, J. and Ozdemir, O, 1982. A comparison of different methods for determining the relative grain size of magnetite in natural sediments: some results from lake sediments. Earth Planet. Sci. Lett., 59: 404-419.

Kligfield, R., Lowrie, W, and Pfiffner. P.A., 1982. Magnetic properties of deformed oolitic limestones from the Swiss Alps: the correlation of magnetic anisotropy and strain. Eclogae Geol. Helv., 75: 127-157.

Lamarche, G. and Rochette, P., 1987. Microstructural analysis and origin of lineations in the magnetic fabric of some Alpine slates. Tectonophysics, 139: 285-293.

MacDonald, W.D. and Ellwood, B.B., 1987. Anisotropy of magnetic susceptibility: sedimentological, igneous, and structural-tectonic applications. Rev. Geophys., 25: 905-909.

Marshak, S., 1986. Structure and tectonics of the Hudson Valley fold-thrust belt, eastern New York State. Geol. Soc. Am. Bull., 97: 354-368.

McCabe, C., Van der Voo, R., Peacor, D.R., Scotese, C.R., and Freeman, R., 1983. Diagenetic magnetite carries ancient yet secondary remanence in some paleozoic sedimentary carbonates. Geology, 11: 221-223.

McCabe, C., Jackson, M., and Ellwood, B.B., 1985. Magnetic anisotropy in the Trenton limestone: results of a new technique, anisotrony of anhysteretic susceptibility. Geophys. Res. Lett., 12: 333-336.

Muller, P. and Siemes, H., 1972. Zur Festigkeit und Gefügeregelung von experimentell verformten Magnetiterzen. Neues Jahrb. Mineral., Abh., 117: 39-60.

Owens, W.H. and Rutter, E.H. 1978. The development of magnetic susceptibility anisotropy through crystallographic preferred orientation in a calcite rock. Phys. Earth Planet. Inter, 16: 215-222.

Rathore, J.S., 1979. Magnetic susceptibility anisotropy in the Cambrian slate belt of North Wales and correlation with strain. Tectonophysics, 53: 83-97.

Rochette, P. and Vialon, P., 1984. Development of planar and linear fabrics in Dauphinois shales and slates (French Alps) studied by magnetic anisotropy and its mineralogical control. J. Struct Geol, 6; 33-38.

Rutter, E.H., 1976. The kinetics of rock deformation by pressure solution. P. Trans. R. Soc. London, Ser. A, 283: 203-219.

Scotese, C.R., Van der Voo, R. and McCabe, C., 1982. Paleomagnetism of the Upper Silurian and Lower Devonian carbonates of New York State: evidence for secondary magnetizations residing in magnetite. Phys. Earth Planet. Inter., 30: 385-395.

Stephenson, A., Sadikun, S. and Potter, D.K., 1986. A theoreti- 
cal and experimental comparison of the anisotropies of magnetic susceptibility and remanence in rocks and minerals. Geophys. J.R. Astron. Soc, 84: 185-200.

Teufel, L.W., 1980. Strain analysis of experimental superposed deformation using calcite twin lamellae. Tectonophysics, 69: 291-309.

Turner, F.J., 1953. Nature and dynamic interpretation of deformation lamellae in calcite of three marbles. Am. J. Sci., 251: 276-298.
Wedel, A.A., 1932. Geologic structure of the Devonian strata of south-central New York. N.Y. State Mus. Bull, 294: 74 pp.

Wiltschko, D.V. and Chapple, W., 1977. Flow of weak rocks in the Appalachian Plateau. Am. Assoc. Pet. Geol. Bull., 61: 653-670. 